Crop Breeding and Applied Biotechnology 12: 151-155, 2012

Brazilian Society of Plant Breeding. Printed in Brazil

NOTE

\title{
Prediction of genotypic values of maize for the agricultural frontier region in northeastern Maranhão, Brazil
}

\author{
Emmanuel Arnhold ${ }^{*}$, Freddy Mora ${ }^{2}$, Cleso Antônio Patto Pacheco ${ }^{3}$ and Hélio Wilson Lemos de Carvalho ${ }^{3}$
}

Received

Accepted

\begin{abstract}
Agricultural research, mainly focused on the evaluation of maize cultivars along agricultural frontiers, are scarce. This study assessed 128 maize genotypes in the agricultural frontier region of the State of Maranhão, between 2008 and 2009. The experiment was arranged in a lattice design with two replications. The genotypes were evaluated for grain yield in a mixed model, with fixed intercept and experimental effects. The random effects were genotype, genetic class (single-, double or triple-cross hybrid and variety), and incomplete block/replication/ environment. The genotype effect was significant by the likelihood ratio test in all models, highlighting the genotypic values of the single-cross hybrids DKB177, AG8088 and DKB390, the triple-cross PL6882, the double-cross BM502 and of the open-pollinated variety SHS3031.
\end{abstract}

Key words: Zea mays L., cultivar, grain yield, REML/BLUP

\section{INTRODUCTION}

The commercial exploitation of maize in the northeastern cerrado region began in the 1980s, in western Bahia, South of Maranhão and in the developing region of Uruçuí- Gurguéia, in the state of Piauí. These areas are appropriate for maize cultivation, in view of the favorable soil conditions and a climate suited for rainfed grain production, aside from a topography that allows mechanized agriculture (Carvalho et al. 2000).

However, in the Brazilian Northeast, the high population density and increasing poultry and pork production have led to a considerable demand for maize. The production of the Brazilian Northeast is insufficient to meet this need, so that large grain quantities must be imported from other regions of the country and from abroad, to complement the regional need (Carvalho et al. 2002). This region has an extensive agricultural frontier where cultivation can be expanded to increase yields (Cardoso et al. 2003).

It is known that higher yields involve a number of factors, above all the correct choice of cultivars adapted to a particular region (Cruz et al. 2004). Every year, several maize cultivars are being released on the market by public and private companies.
These should be evaluated, to identify those with highest yield potential for the regional environmental conditions (Cardoso et al. 2003). Thus, considering the differences in environments and in production systems, the evaluation of maize cultivars seems interesting, as an orientation for farmers when choosing these materials (Carvalho et al. 2005).

In this context, it should be noted that the northeastern region of Maranhão (Lower Parnaíba Region), in the far north of the mid-north region of Brazil, is promising for agricultural expansion. The area is suitable for mechanized farming, and also located near the harbor of São Luis, whose location favors the grain export to countries in Europe and the USA. The region can also become a center of regional development and produce food for northern and northeastern Brazil. However, little scientific or technical data are available for this specific region that could serve as guidelines for producers who are often rely on empirical methods to search for new technologies and increase productivity (Arnhold et al. 2010).

Another important aspect to be taken into consideration is the statistical methodology used to evaluate the genotypes. For Resende and Duarte (2007), the estimators of Value for Cultivation and Use (VCU) should almost always be based

\footnotetext{
${ }^{1}$ Universidade Federal de Goiás, Campus Samambaia, C.P. 131, 74.001-970, Goiânia, GO, Brazil. *E-mail: earnhold@pq.cnpq.br

2 Instituto de Biología Vegetal y Biotecnología, Universidad de Talca, 2 Norte 685, Talca, Chile

${ }^{3}$ Embrapa Tabuleiros Costeiros, Avenida Beira Mar, 3250, Jardins, C. P. 44, 49.025-040, Aracajú, Sergipe, Brazil
} 
on random or mixed models with random effects of genetic treatments for the use of intergenotypic information derived from this assumption of randomness. In this context in plant breeding, the estimation of variance components and prediction of genetic values are key aspects in the quantitative genetic analysis of economically important traits. By the mixed linear model methodology, it is possible to calculate the BLUP (Best Linear Unbiased Prediction) of the random effects, in this case the genetic gain, by maximizing the combined density function considering the fixed and random effects of the mixed model. The prediction of random effects of the mixed model depends on the accuracy of the variance component estimates, which are preferably estimated by the REML (Restricted Maximum Likelihood) procedure. According to Borges et al. (2010), REML / BLUP methods are nowadays the most accurate methods for analyses in a wide range of applications, advantageously replacing the method of analysis of variance, especially in cases of experiments with a certain degrees of imbalance.

According to Maia et al. (2011), mixed models would be more realistic, with more accurate results. According to the same authors, more refined genetic-statistical procedures, e.g., the variance component estimation and mean component prediction by REML / BLUP are upcoming trends in plant breeding.

In fact, mixed models with prediction of genotypic values have been used in several studies, for perennial, semi-perennial as well as annual plants (Oliveira et al. 2005, Carbonnel et al. 2007, Bastos et al. 2007, Piepho et al. 2007, Pedrozo et al. 2008, Arnhold et al. 2009, Maia et al. 2009, Borges et al. 2010, Maia et al. 2011).

Piepho et al. (2007) discussed the usefulness of linear mixed models in the advanced stages of cultivar selection (i.e., in VCU trials, considering tests in multiple environments). The researchers demonstrated that the Restricted Maximum Likelihood was preferable to the Maximum Likelihood (ML; Maximum Likelihood), in the estimation of variance components. In turn, in the VCU trials, BLUP is preferable to the BLUE (Best Linear Unbiased Estimator), justifying the use of genotype as random effect.

Thus, this study was carried out to predict genotypic values (BLUPs) of maize genotypes in the region of the agricultural frontier in the northeastern state of Maranhão.

\section{MATERIAL AND METHODS}

Between 2008 and 2009, 128 different maize genotypes were evaluated in three experiments, divided into three environments, along the agricultural frontier in the northeastern state of Maranhão. Three trials were carried out: 1) a $6 \times 7$ lattice with single, triple and double-cross hybrids; 2) a 6 $\mathrm{x} 7$ lattice with single, triple and double-cross hybrids and open-pollinated varieties and 3) a 7 × 8 lattice with single, triple and double-cross hybrids and open-pollinated varieties. The lattices were replicated twice and involved 12 common genotypes in at least two experiments.

Experiment 1 was evaluated in two environments, one beginning on February 14, 2008, in Anapurus and the other on February 18, 2008, in Brejo. Experiment 2 was evaluated in an environment, installed on February 15, 2008, in Anapurus. Experiment 3 was evaluated in an environment in Chapadinha, beginning on February 13, 2009. All three environments are located in the northeastern state of Maranhão, along the agricultural frontier of the region known as the Lower Parnaíba of Maranhão.

In all experiments, each plot consisted of four 5-m rows, spaced $0.90 \mathrm{~m}$ apart. Plants were thinned to 25 seedlings per row, corresponding to a population of approximately 55,555 plants $\mathrm{ha}^{-1}$. Fertilization was tailored for each experiment according to the results of soil analyses for each experimental area. Each plot corresponded to the two complete central rows, totaling an evaluated area of $9.0 \mathrm{~m}^{2}$. In this area, the threshed grain weight $\left(\mathrm{kg} \mathrm{plot}^{1}\right)$ and moisture (\%) were determined. Prior to the statistical analyses, grain moisture was standardized at $15 \%$ and grain weight was transformed from $\mathrm{kg} \mathrm{plot}^{-1}$ to $\mathrm{kg} \mathrm{ha}^{-1}$.

The genotypes were evaluated by the following mixed model, in which grain yield was a response variable (GY, $\mathrm{kg} \mathrm{ha}^{-1}$ ).

$\mathrm{y}_{\mathrm{ijkb(r)(a)}}=\mu+\alpha_{\mathrm{i}}+\beta_{\mathrm{j}}+\gamma_{\mathrm{k}}+(\mathrm{B} / \mathrm{R} / \mathrm{A})_{\mathrm{b}(\mathrm{r})(\mathrm{a})}+\mathrm{e}_{\mathrm{ijkb(r)(a)}}$ where:

- $\mathrm{y}_{\mathrm{ijkb(r)(a)}}$ is the observed value in experiment $\mathrm{i}(\alpha: \mathrm{i}=1,2,3)$, of genotype $\mathrm{j}(\beta: \mathrm{j}=1,2,3, \ldots, 128)$, which belongs to gene class $\mathrm{k}(\gamma: \mathrm{k}=1,2,3,4)$, in the incomplete block $\mathrm{b}(\mathrm{B}: \mathrm{b}=1,2,3, \ldots, 22)$, within replication $\mathrm{r}(\mathrm{R}: \mathrm{r}=1,2)$, of environment $\mathrm{a}(\mathrm{A}: \mathrm{a}=1,2,3)$;

- $\mu$ : constant (intercept) inherent to all observations;

- $\alpha$ : fixed effect of experiment $i(\alpha: i=1,2,3)$;

- $\beta$ : random effect of genotype $j(\beta: j=1,2,3, \ldots, 128)$, assuming $\sim \mathrm{NID}\left(0, \sigma_{\mathrm{g}}^{2}\right)$;

- $\gamma$ : genetic random effect of class $\mathrm{k}(\gamma: \mathrm{k}=1,2,3,4)$, assuming $\sim \mathrm{NID}\left(0, \sigma_{\mathrm{c}}^{2}\right)$;

- $(\mathrm{B} / \mathrm{R} / \mathrm{A})_{\mathrm{b}(\mathrm{r})(\mathrm{a})}:$ effect of incomplete block $\mathrm{b}(\mathrm{B}: \mathrm{b}=1,2,3, \ldots, 22)$, within the replication $r(R: r=1,2)$, within the environment $\mathrm{a}(\mathrm{A}: \mathrm{a}=1,2,3)$, assuming $\sim \mathrm{NID}\left(0, \sigma_{\mathrm{b}}^{2}\right)$;

- $\mathrm{e}_{\mathrm{ijkb(r)(a)}}$ : effect of the random errors associated with the observation $\mathrm{y}_{\mathrm{ijkb(r)(a)} \text {, }}$, assuming $\sim \mathrm{NID}\left(0, \sigma_{e}^{2}\right)$;

- and also assuming that $\beta_{\mathrm{j}}, \gamma_{\mathrm{k}},(\mathrm{B} / \mathrm{R} / \mathrm{A})_{\mathrm{b}(\mathrm{r})(\mathrm{a})}$ : and $\mathrm{e}_{\mathrm{ijkb(r)(a)}}$ are independent. 
The component "genetic class" was included in the model to correct the imbalance between experiments in relation to the number of single, double and triple-cross hybrids and varieties, which would be confused with the environmental effect.

The genetic class was considered random, for representing a sample of each assessed genetic class. The same applies to the use of incomplete blocks, considered random. But the genotypes were considered random according to the observations of Resende and Duarte (2007). For these authors, the effects of genetic treatments should be considered random when the number of treatments is greater than 10 , to minimize the mean square error in the estimation of the true genetic values.

Fritsche-Neto et al. (2010) concluded that the prediction of genotypic values is little affected by an imbalance of up to $20 \%$ for genotypes. Despite the severe imbalance observed in this study, it was understood that this way of estimating the genotypic values, using REML/BLUP was the best to evaluate this genotype set, since in animal breeding, BLUPs are estimated with very severe imbalances. The genotype $\mathrm{x}$ environment interaction was not investigated since the differences between environments in the region were small and the imbalance considerable, which could generate imprecise estimates.

The significance of the effects of genotypes and of other random components of the model were checked by the likelihood ratio test (Arnhold et al. 2009). The Spearman correlation was used to evaluate the correlations between the genotype ranking based on their genotypic and phenotypic means.

These analyses were performed using software $R$ ( $R$ Development Core Team 2011) and the package for analysis of mixed models called lme4 (Bates and Bolker 2011). In the lme4 package, the lmer function was used, with variance component estimation by REML.

\section{RESULTS AND DISCUSSION}

The overall mean of 128 genotypes was $4892 \mathrm{~kg} \mathrm{ha}^{-1}$, which is still low in view of the potential yield of maize, but is similar to the averages found in experiments with maize in northeastern Brazil, as reported by Souza et al. (2002), Cardoso et al. (2003), Carvalho et al. (2000), Carvalho et al. (2002), Carvalho et al. (2005) and Arnhold et al. (2010). In a study with hybrids only, Arnhold et al. (2010) recorded an average of $5593 \mathrm{~kg} \mathrm{ha}^{-1}$, while in this study open-pollinated varieties were evaluated as well.
In the Lower Parnaíba region of Maranhão, maximum yields reported by producers are around $6000 \mathrm{~kg} \mathrm{ha}^{-1}$ on mechanized farms using modern hybrids. The difficulty of increasing yields is caused mainly by the adverse conditions of climate and soil and the lack of genotypes adapted to these conditions. In this context, the high night temperatures (minimum frequently above $24{ }^{\circ} \mathrm{C}$ ) are particularly injurious, aside from heavy rainfalls that facilitate nutrient leaching, which is especially problematic because of the excessively sandy soils of the region. According to Galon et al. (2010), high night temperatures and nitrogen deficiency are among two of the main factors affecting maize production.

The genotypic variance, together with the other random components, was statistically significant $(\mathrm{p}<0.05)$ by the likelihood ratio test, indicating the possibility of effective selection based on BLUPs of the genotype effect.

The estimated Spearman correlation of the BLUP ranking based on the genotype means was $0.75(p<0.05$ by the $t$ test). This result demonstrates that the selection based on the phenotypic means would not select the same genotypes. However, most selected genotypes would be common to a selection based on BLUP ranking. The variance components, determined by REML, also play an important role in the context of mixed models. In fact, according to Resende and Duarte (2007), the precise estimation of variance components is fundamental since it can enhance the accuracy of the genetic values of genotypes and, consequently, the identification of genetically superior plants. Therefore, when information from the agronomic data set is lost, the REML method is preferable.

The best 15 genotypes according to BLUP (Table 1) show that the single-cross hybrids are superior. This fact was expected, since single-cross generally performs better than triple-cross hybrids, which are generally better than the double-cross, which are in turn generally superior to the open-pollinated varieties (Alves et al. 2006, Emygdio et al. 2007, Arnhold et al. 2010). In this study, the yield means of the single, triple and double-cross hybrids and open-pollinated varieties were 5742, 4933, 4634, and $3322 \mathrm{~kg} \mathrm{ha}^{-1}$, respectively, while the BLUPs of the genetic class of the same were 917, 255, 29, and -1201 , respectively.

The best-performing of the large number of assessed genotypes were the single-cross hybrids DKB177, AG8088 and DKB390, the triple-cross hybrids PL6882, the doublecross hybrids BM502, and the open-pollinated variety SHS3031 (Table 1). The genotypes DKB177, AG8088 and 
Table 1. The 15 best genotypes by their respective BLUPs, with their respective genetic classes

\begin{tabular}{lcc}
\hline Genotypes & BLUPs & Genetic Classes \\
\hline DKB177 & 691 & HS \\
\hline AG8088 & 690 & HS \\
\hline BM502 & 667 & HD \\
\hline DKB390 & 640 & HS \\
\hline SHS3031 & 548 & V \\
\hline AS1567 & 543 & HS \\
\hline P30P70 & 520 & HS \\
\hline XB8030 & 505 & HD \\
\hline Balu761 & 501 & HD \\
\hline BRS3025 & 455 & HS \\
\hline PL6882 & 439 & HT \\
\hline GNZ9501 & 413 & HS \\
\hline P30F35 & 392 & HS \\
\hline ALVORADA & 375 & V \\
\hline CD308 & 370 & HT \\
\hline * HS: single-cross hybrid; HT: triple-cross hybrid; HD: double-cross hybrid; &
\end{tabular}

DKB390 are single-cross hybrids sold by their companies as high yielding for vast growing regions of Brazil. These are the most indicated genotypes for exploitation on the mechanized farms of the region. The hybrids PL6882 and BM502 and the open-pollinated variety SHS3031 can be used on less mechanized, smaller farms. All these genotypes can be utilized in crosses with local varieties to obtain lines for the development of hybrids with a high regional performance.

Considering that the means of some of the genotypes were above $7000 \mathrm{~kg} \mathrm{ha}^{-1}$, it is concluded that the use of these lines can contribute very significantly to the intensification of maize cultivation in this region.

\section{CONCLUSIONS}

The likelihood ratio test indicated a significant genotype effect, and highest genotypic values of the single-cross hybrids DKB177, AG8088 and DKB390, the triple-cross hybrid PL6882, double cross hybrid BM502 and the open-pollinated variety SHS3031. These genotypes are recommended for direct use in planting or in breeding programs for the development of hybrids and varieties for the region.

\section{ACKNOWLEDGEMENTS}

The authors are indebted to the National Council for Scientific and Technological Development (CNPq) and the Bank of Northeast Brazil (BNB) for financial support. They also wish to thank the Brazilian Agricultural Research Corporation (Embrapa) for providing the test seeds.

\section{Predição de valores genotípicos de milho para região de fronteira agrícola no nordeste do Maranhão}

Resumo - É escassa a realização de pesquisas agronômicas com o milho em fronteiras agrícolas, principalmente quanto à avaliação de cultivares. Assim, objetivou-se avaliar 128 genótipos entre 2008 e 2009 em região de fronteira agrícola no Estado do Maranhão. Os experimentos foram delineados em látices com duas repetições. Os genótipos foram avaliados pela produção de grãos em modelo misto, tendo como efeitos fixos o intercepto e o efeito de experimento. Os efeitos aleatórios foram os de genótipos, classe genética (híbrido simples, triplo ou duplo e variedade) e bloco incompleto/repetição/ambiente. O efeito de genótipo foi significativo pelo teste da razão da verossimilhança em todos os modelos, destacando-se os valores genotípicos dos híbridos simples DKB177, AG8088 e DKB390, o híbrido triplo PL6882, o híbrido duplo BM502 e a variedade de polinização aberta SHS3031.

Palavras-chave: Zea mays L., cultivar, rendimento de grãos, REML/BLUP.

\section{REFERENCES}

Alves SJ, Toledo JFF, Araújo PM and Garbuglio DD (2006) Comportamento de diferentes classes genéticas de milho quanto à adaptabilidade e estabilidade. Revista Brasileira de Milho e Sorgo 5: 291-303.

Arnhold E, Mora F, Silva RG, Good-God PIV and Rodovalho MA (2009) Evaluation of top-cross popcorn hybrids using mixed linear model methodology. Chilean Journal of Agricultural Research 69: $46-53$.

Arnhold E, Pacheco CAP, Carvalho HWL, Silva RG and Oliveira Júnior EA (2010) Produtividade de híbridos de milho em região de fronteira agrícola no nordeste do Maranhão. Revista Brasileira de Ciências Agrárias 5: 468-473.
Bastos I T, Barbosa MHP, Resende MDV, Peternelli LA, Silveira LCI, Donda LR, Fortunato A A, Costa PMA and Figueiredo ICR (2007) Avaliação da interação genótipo x ambiente em cana-de-açúcar via modelos mistos. Pesquisa Agropecuária Brasileira 37: 195-203.

Bates D and Bolker MMB (2011) lme4: Linear mixed-effects models using S4 classes. R package version 0.999375-39. Available at $<$ http:// CRAN.R-project.org/package $=$ lme4 $>$ assessed in 2011.

Borges V, Ferreira PV, Soares L, Santos GM and Santos AMM (2010) Seleção de clones de batata-doce pelo procedimento REML/BLUP. Acta Scientiarum Agronomy 32: 643-649. 
E Arnhold et al.

Carbonell SAM, Chiorato AF, Resende MDV, Dias LAS, Beraldo ALA and Perina EF (2007) Estabilidade de cultivares e linhagens de feijoeiro em diferentes ambientes no estado de São Paulo. Bragantia 66: 193-201.

Cardoso MJ, Carvalho HWL, Santos MX, Leal MLS and Oliveira AC (2003) Desempenho de híbridos de milho na região meio-norte do Brasil. Revista Brasileira de Milho e Sorgo 2: 43-52.

Carvalho HWL, Cardoso MJ, Leal MLS, Santos MX, Tabosa JN and Souza EM (2005) Adaptabilidade e estabilidade de cultivares de milho no Nordeste brasileiro. Pesquisa Agropecuária Brasileira 40: 471-477.

Carvalho HWL, Leal MLS, Cardoso MJ, Santos MX, Tabosa JN, Santos MD and Lira MA (2002) Adaptabilidade e estabilidade de híbridos de milho em diferentes condições ambientais do nordeste brasileiro. Revista Brasileira de Milho e Sorgo 1: 75-82.

Carvalho HWL, Leal MLS, Santos MX, Monteiro AAT, Cardoso MJ and Carvalho BCL (2000) Estabilidade de cultivares de milho em três ecossistemas do nordeste brasileiro. Pesquisa Agropecuária Brasileira 35: 1773-1781.

Cruz CD, Regazzi AJ and Carneiro PCS (2004) Modelos biométricos aplicados ao melhoramento genético. Editora UFV, Viçosa, 480p.

Emygdio BM, Ignaczak JC and Cargnelutti-Filho A (2007) Potencial de rendimento de grãos de híbridos comerciais simples, triplos e duplos de milho. Revista Brasileira de Milho e Sorgo 6: 95-103.

Fritsche-Neto R, Gonçalves MC, Vencovsky R and Souza-Júnior CL (2010) Prediction of genotypic values of maize hybrids in unbalanced experiments. Crop Breeding and Applied Biotechnology 10: 32-39.

Galon L, Tironi SP, Rocha AA, Soares ER, Concenço G and Alberto CM (2010) Influência dos fatores abióticos na cultura do milho. Revista Trópica - Ciências Agrárias e Biológicas 4: 18-38.
Maia MCC, Resende MDV, Oliveira LC, Álvares VS, Maciel VT and Lima AC (2011) Seleção de clones experimentais de cupuaçu para características agroindustriais via modelos mistos. Revista Agro@ mbiente 5: 35-43.

Maia MCC, Resende MDV, Paiva JR, Cavalcanti JJV and Barros LM (2009) Seleção simultânea para produção, adaptabilidade e estabilidade genotípicas em clones de cajueiro, via modelos mistos. Pesquisa Agropecuária Tropical 39: 43-50.

Oliveira RA, Resende MDV, Daros E, Bespalhok Filho JC, Zambon JLC, Ido OT, Weber H and Koehler HS (2005) Genotypic evaluation and selection of sugarcane clones in three environments in the state of Paraná. Crop Breeding and Applied Biotechnology 5: 426-434.

Pedrozo CA, Barbosa MHP, Resende MDV, Peternelli LA, Costa PMA and Silva FL (2008) Eficiência da seleção em fases iniciais do melhoramento da cana-de-açúcar. Revista Ceres 55: 1-8.

Piepho HP, Möhring J, Melchinger AE and Büchse A (2007) BLUP for phenotypic selection in plant breeding and variety testing. Euphytica 161: $207-209$.

R Development Core Team (2011) R: A language and environment for statistical computing. R Foundation for Statistical Computing, Vienna, Austria. ISBN 3-900051-07-0. Available at < http://www.R-project. org/> assessed in 2011.

Resende MDV and Duarte JB (2007) Precisão e controle de qualidade em experimentos de avaliação de cultivares. Pesquisa Agropecuária Tropical 37: 182-194.

Souza FRS, Ribeiro PHE, Veloso CAC and Corrêa LA (2002) Produtividade e estabilidade fenotípica de cultivares de milho em três municípios no Estado do Pará. Pesquisa Agropecuária Brasileira 37: 1269-1274. 